\title{
A Study on the Microbial Quality of Drinking Water in Rural Areas of Mazandaran Province in North of Iran (2011)
}

\author{
Abdoliman Amouei ${ }^{1}$, Mohammad Bagher Miranzadeh ${ }^{2}$, Zahra Shahandeh ${ }^{3 *}$, Tahereh Taheri ${ }^{4}$, \\ Hossein Ali Asgharnia ${ }^{1}$, Samaneh Akbarpour ${ }^{5}$, Bahram Mokari ${ }^{4}$ \\ ${ }^{1}$ Environmental Health Engineering Department, Babol University of Medical Sciences, Babol, Iran; ${ }^{2}$ Environmental Health \\ Engineering Department, Kashan University of Medical Sciences, Kashan, Iran; ${ }^{3}$ Laboratory Sciences Department, Paraclinical \\ Faculty, Babol University of Medical Sciences, Babol, Iran; ${ }^{4}$ Environmental Health Graduated of Babol University of Medical \\ Sciences, Babol, Iran; ${ }^{5}$ Social Medicine Department, Babol University of Medical Sciences, Babol, Iran. \\ Email: *shahandeh_za@yahoo.com
}

Received March 21 ${ }^{\text {st }}, 2012$; revised April 28 ${ }^{\text {th }}, 2012$; accepted May $27^{\text {th }}, 2012$

\begin{abstract}
Backgrounds: One of the fundamental needs of a community is to have an access to healthy and safe drinking water. The lack of a concentrated accessibility to health facilities and services is among the serious problems facing villagers in the rural areas. The aims of this research was to investigate the drinking water quality of the villages in Babol township suburbs in north of Iran. Materials and Methods: In this cross-sectional descriptive study, a total of 140 water samples were taken from the water distribution network in 16 villages for the low and high-rain seasons in sterile glass bottle. The microbial quality of gathered samples were determined based on standard methods in laboratory. Statistical analysis of the results was performed using a SPSS16 statistical software. Findings: Based on obtained results $13.6 \%$ of the samples were contaminated to coliform and $20 \%$ to fecal coliform bacteria. The residual chlorine in $12.5 \%$ of the samples were between 0.2 to $0.8 \mathrm{mg} \cdot \mathrm{L}^{-1}$ and the $\mathrm{PH}$ in total samples were between 6.8 to 7.8 . There were no signs of any contamination for $32.86 \%$ of the analysed samples which water resources is located to a distance of more than $30 \mathrm{~m}$ to the contamination sources. In addition, $43.1 \%$ of the samples taken from the water resources with no plumbing system, have had a fecal contamination. Conclusions: Considering the results achieved, the microbial quality of the drinking water of the studied villages classified as "moderate" status. For more water supply there is not sufficient residual chlorine in most cases. Poor sanitation of water supply is most causes of water contamination. It is therefore strongly recommended that sanitation measures are made to protect water resources from the contamination.
\end{abstract}

Keywords: Microbial Quality; Drinking Water; Rural Water Supply; Disinfection

\section{Introduction}

Water is the source of life and human needs the safe drinking water for health and sanitary purposes thus, it is of importance to try for its provision. It is an essential problem in developing countries to provide safe drinking water for human consumption [1]. Contamination of water resources is occurred due to poor water resources sanitation, animal manure, improper disposal of solid waste and domestic sewage [2,3]. It is evidently important to control ground and surface water from the contamination. It is necessary to have a continuous monitoring on the water quality through microbial and chemical examinations. In general, safe drinking water should not have any infectious agents or contain unacceptable level

"Corresponding author. of chemicals that dangerous to human health and should be aesthetically acceptable to the consumer. Infectious agent that find in drinking water in the first place are those caused by fecal contamination [4].

The indicator organisms include total and fecal coliforms bacteria have the highest application for determining microbial quality of the drinking water. Although total coliforms bacteria have been used as the basis of the drinking water quality evaluation, but their abilities to survive in the environment or in the drinking water distribution system introduces them as an unreliable indicator against the fecal contamination $[5,6]$. Based on WHO and Iranian drinking water standard, drinking water must be without any fecal coliforms bacteria in each $100 \mathrm{ml}$ of water sample $[7,8]$.

Regarding to authorized reports during the year 2007, 
more than $54 \%$ of the rural areas with a population of over 20,000 habitants is covered by water company services in Iran. In rural areas of Iran, disinfection of drinking water is only water treatment process before feeds to water network. The chlorination of water is conventional methods of disinfection .Maintaining a residual chlorine of 0.2 to $0.8 \mathrm{mg} \cdot \mathrm{L}^{-1}$ is necessary for secondary pollution control in distribution system $[9,10]$. The aims of current study were to investigate the microbial quality of drinking water in rural areas of Babol city in north of Iran.

\section{Materials and Methods}

These cross-sectional descriptive studies were conducted on microbial quality of water in 16 villages in babol city in the north of Iran (Mazandaran province) during the summer and winter 2010. Location of studied villages is shown in Figure 1.

In order to determine the microbial quality of drinking water in the villages, two factors including free residual chlorine and fecal contamination indicator along with $\mathrm{PH}$ were chosen as the criteria for determination of water quality. Water is supplied by Springs, deep and shallow wells in studied village. A total of 140 sample (70 sample in each season) were taken from the water consuming points. Sample for microbial test is collected in sterile glass bottle with $300 \mathrm{~mL}$ capacity. Residual chlorine test and $\mathrm{PH}$ were determined as on-site. After collection, samples were transferred to the microbiological lab of paraclinical faculty, Babol university of medical sciences and then analyzed for coliform bacteria according to standard methods [11]. In addition, the type of water network and distance of water supply to the contamination sources were recorded during sampling. Finally, obtained data were analyzed based on general statistical parameters using SPSS software.

\section{Results}

The concentration of residual chlorine and $\mathrm{pH}$ in the drinking water of studied villages are shown in Table 1. As indicated in this table the mean concentration of the residual chlorine in analyzed sample were $0.65,0.35$ in summer and winter, respectively. In addition, $\mathrm{pH}$ value is vary between 6.8 to 7.8 in two season.

The microbial quality of the drinking water in studied villages as type of water supply was shown in Table 2 . As shown in this table, $43.2 \%$ of water sample in spring is without of contamination and $43.2 \%$ were contaminated with fecal sources. For deep well, $60.5 \%$ of sample haven't contamination and $14.2 \%$ contaminated with fecal coliforms.

The fecal and total coliforms bacteria that is separated from the analysed samples consist of Escherichia coli (71\%), Enthrobacter klocae (1\%), Clebcia pneumonae $(11 \%)$, anterbacter aerogens $(12 \%)$, bacillius $(3 \%)$ and pseudomonas Aeroginoza (2\%).The number of fecal coliform in $18.6 \%$ of samples was about $1100 \mathrm{MPN} / 100 \mathrm{ml}$. Forty seven percent of the samples which were taken from the unpiped water system indicate fecal contamination.

The results of microbial quality of studied drinking water regarding to presence and absence of water piping system is shown in Table 3. As indicated in this table, $43.1 \%$ of unpiped sample were contaminated with fecal and $39.2 \%$ non-fecal pollution.

The obtained results revealed that $60.5 \%$ of water sample were taken from water supply which located to a dis-

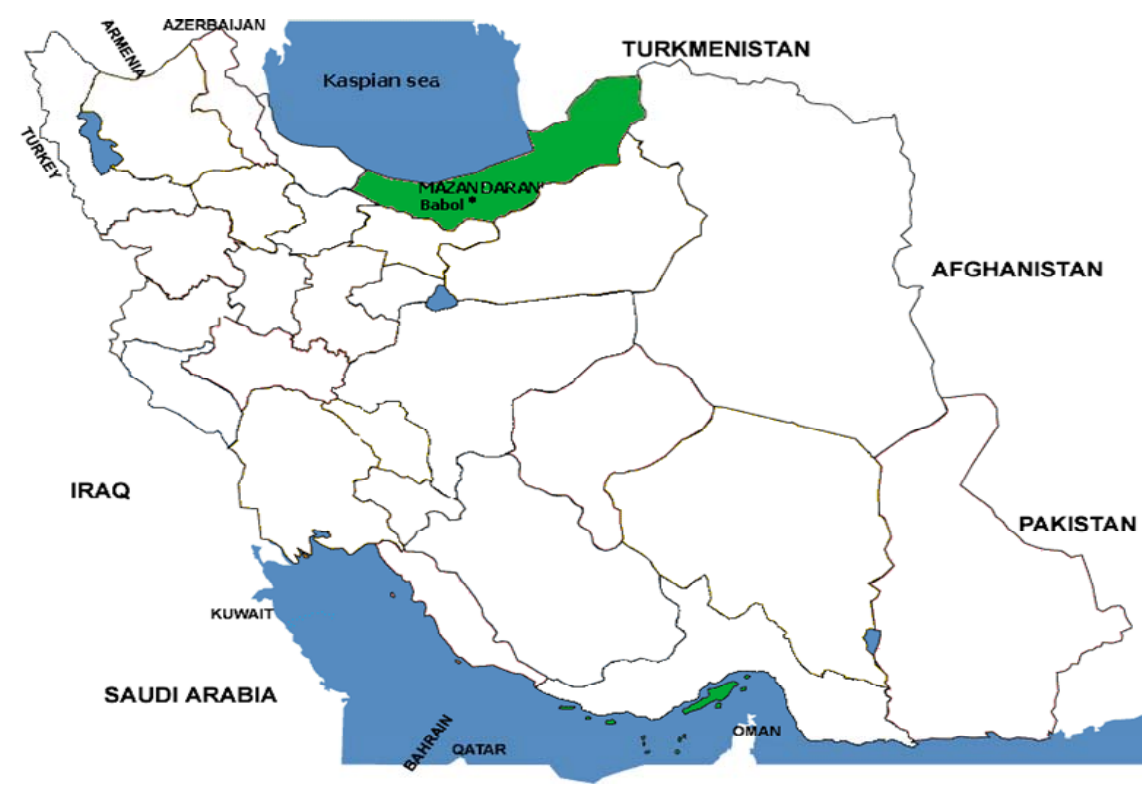

Figure 1. Location of investigated area. 
Table 1. The concentration of residual chlorine and $\mathrm{pH}$ in the drinking water of studied villages.

\begin{tabular}{cccccc}
\hline Parameter & Season & Mean & Standard deviation & Maximum & Minimum \\
\hline \multirow{2}{*}{ Free residual chlorine $\left(\mathrm{mg} \cdot \mathrm{L}^{-1}\right)$} & summer & 0.65 & 0.62 & 1.5 & 0 \\
& winter & 0.35 & 0.23 & 0.8 & 0 \\
$\mathrm{pH}$ & summer & 6.9 & 0.2 & 7.4 & 6.8 \\
& winter & 7.4 & 0.33 & 7.8 \\
\hline
\end{tabular}

Table 2. The microbial quality of the drinking water in studied villages as type of water supply.

\begin{tabular}{ccccccccc}
\hline \multirow{2}{*}{ Type of water supply } & \multicolumn{2}{c}{ Contamination free } & \multicolumn{2}{c}{ Non-fecal contamination } & \multicolumn{2}{c}{ Fecal contamination } & \multicolumn{2}{c}{ Total } \\
\cline { 2 - 8 } & No. of sample & $\%$ & No. of sample & $\%$ & No. of sample & $\%$ & No. of sample & $\%$ \\
\hline Spring & 16 & 43.2 & 6 & 16.3 & 15 & 40.5 & 37 & 100 \\
Shallow well & 6 & 50 & 6 & 50 & 0 & 0 & 12 & 100 \\
Deep well & 55 & 60.5 & 23 & 25.3 & 13 & 14.2 & 91 & 100 \\
\hline
\end{tabular}

Table 3. Microbial quality of studied drinking water regarding to presence and absence of water piping system.

\begin{tabular}{|c|c|c|c|c|c|c|c|c|}
\hline \multirow{2}{*}{ Type of water system } & \multicolumn{2}{|c|}{ Contamination free } & \multicolumn{2}{|c|}{ Non-fecal contamination } & \multicolumn{2}{|c|}{ Fecal contamination } & \multicolumn{2}{|l|}{ Total } \\
\hline & No. of sample & $\%$ & No. of sample & $\%$ & No. of sample & $\%$ & No. of sample & $\%$ \\
\hline Unpiped & 18 & 17.7 & 40 & 39.2 & 44 & 43.1 & 102 & 100 \\
\hline Piped & 22 & 57.9 & 10 & 26.3 & 6 & 15.8 & 38 & 100 \\
\hline
\end{tabular}

tance of more than 15 meters away of the contamination sources have fecal pollution and $23.7 \%$ were without contamination. For water supply with less than $15 \mathrm{~m}$ distance to contamination sources only $15.6 \%$ of water sample shows fecal pollution (Table 4).

The results of microbial quality of the analyzed water samples with respect to the season of year were shown in Table 5. Although in our study, non-fecal contamination cases of the water samples were more in summer $(38.6 \%)$ rather than winter $(14.3 \%)$ but, fecal contamination cases of the samples were more in winter $(35.7 \%)$ rather than summer $(32.9 \%)$. No significant statistical correlation has been established between the microbial contamination of water and the season of year.

\section{Discussion}

On the basis of Iranian and WHO drinking water standards, drinking water should be without of any fecal coliforms bacteria [12]. In our study, $66.4 \%$ of analyzed sample were uncontaminated, $20 \%$ fecal contaminated and $13.6 \%$ non-fecal contaminated. According to WHO guideline, the microbial water quality of studied villages is classified as "moderate" quality [13]. Regarding to other study, $93.07 \%$ of water supply in Iranian villages was in "good" status .In addition, findings of a study in villages in west of Iran during 2009 were shown that in
$88 \%$ of sample results of the microbial test were negative which is incompatible with our study findings (67\%). This difference is due to poor water supply sanitation, improper disposal of sewage and solid waste in studied region [14]. In a research in India it is revealed that $68.9 \%$ of the water samples are not appropriate for drinking [15-17]. Therefore it can be said that the drinking water contamination is an important problem in most of the developing countries.

Based on Iranian standard, maintaining a residual chlorine of 0.5 to $0.8 \mathrm{mg} \cdot \mathrm{L}^{-1}$ in drinking water is required to protect secondary pollution and public health improvement [18]. Our study findings indicate that residual chlorine in $12.5 \%$ of the drinking water samples tested was in the range of 0.2 to $0.8 \mathrm{mg} \cdot \mathrm{L}^{-1}$ which were compatible with the drinking water standards of USEPA and WHO and/for remaining sample were less than 0.2 $\mathrm{mg} \cdot \mathrm{L}^{-1}$ that do not math mentioned standards. This figure was $28 \%$ in shadegan city (south of Iran) during 2010 that is approximately agree with our study findings. For many decades the conventional methods for water disinfection in rural region is chlorination. Many parameters effect chlorination efficiency [19-21].

In this study we find that $53 \%$ of villages have water distribution system and $47 \%$ unpiped system. A strong correlation between microbial quality of water and type of water supply, distance and piped or unpiped system 
Table 4. Microbial quality of the studied water samples regarding to distance of water resources against contamination point.

\begin{tabular}{|c|c|c|c|c|c|c|c|c|}
\hline \multirow{2}{*}{ Distance } & \multicolumn{2}{|c|}{ Contamination free } & \multicolumn{2}{|c|}{ Non-fecal contamination } & \multicolumn{2}{|c|}{ Fecal contamination } & \multicolumn{2}{|c|}{ Total } \\
\hline & No. of sample & $\%$ & No. of sample & $\%$ & No. of sample & $\%$ & No. of sample & $\%$ \\
\hline More than 15 meter & 18 & 23.7 & 12 & 15.8 & 46 & 60.5 & 76 & 100 \\
\hline Less than 15 meter & 40 & 62.5 & 14 & 21.9 & 10 & 15.6 & 64 & 100 \\
\hline
\end{tabular}

Table 5. Microbial quality of the studied water samples regarding to the season of year.

\begin{tabular}{ccccccccc}
\hline \multirow{2}{*}{ Season } & \multicolumn{2}{c}{ Contamination free } & \multicolumn{2}{c}{ Non-fecal contamination } & \multicolumn{2}{c}{ Fecal contamination } & \multicolumn{2}{c}{ Total } \\
\cline { 2 - 9 } & No. of sample & $\%$ & No. of sample & $\%$ & No. of sample & $\%$ & No. of sample & $\%$ \\
\hline \multirow{2}{*}{ Summer } & 20 & 28.5 & 27 & 38.6 & 23 & 32.9 & 70 & 100 \\
Winter & 35 & 50 & 10 & 14.3 & 25 & 35.7 & 70 & 100 \\
\hline
\end{tabular}

were obtained by linear regression analysis but weren't found a relationship between microbial quality and season of year. This demonstrates that water resources with horizontal distance less than $15 \mathrm{~m}$ from the pollution sources are more susceptible to fecal contamination. With respect to Iranian regulations, for pollution prevention the minimum horizontal distance between water and sewage well must be 15 meter. In studied villages, $28 \%$ do not satisfy mentioned regulations [22].

Also, springs were more susceptible rather than deep well to pollution. The level of microbial contamination in all water resources were almost equal in both low-rain (summer) and high-rain (winter) seasons. In addition, unpiped water supply shows more fecal contamination due to improper sanitation. Well sanitation plays an important role in pollution prevention [22].

\section{Conclusion}

Considering the obtained results, in spite of disinfection, the microbial contamination of drinking water in rural areas is an important problems. Most causes of water contamination is due to inefficient chlorination, poor sanitation, improper disposal of wastes and no piping system. To protect water supply from the contamination it is strongly recommended that rehabilitation of water system,maintaining sufficint residual chlorine and continuos monitoring were made.Also, piping of drinking water supply plays an important role to pollution prevention.

\section{Acknowledgements}

The respected departments of health, research and technology of the Babol University of Medical Sciences and other colleagues who have helped us in this research are cordially acknowledged and appreciated.

\section{REFERENCES}

[1] A. H. Mahvi, "Health and Aesthetic Aspects of Water Quality," Bal Gostar Publication, Tehran, 1996 (in Persian).

[2] M. Norisepehr, "Guidelines for Drinking Water," Hayyan Publication, Tehran, 1994 (in Persian).

[3] J. Salvato, N. L. Nemerow and F. J. Agardy, "Environmental Engineering Sanitation," 5th Edition, John Wiley and Sons, Washington DC, 2003.

[4] P. Payment, M. Wait and A. Dufour, "Introducing Parameters for the Assessment of Drinking Water Quality: In Assessing Microbial Safety of Drinking Water, Improving Approaches and Methods," IWA Publishing, London, 2004.

[5] World Health Organization, "Guidelines for Drinking Water Quality, Third Edition, Incorporating the First and Second Addenda," 2008.

[6] J. Bartram, J. Cotruvo, M. Exner, C. Fricker and A. Glasmacher, "Heterotrophic Plate Counts and Drinking-Water Safety: The Significance of HPCs for Water Quality and Human Health," IWA Publishing, London, 2003.

[7] IRSIR, "Standards of Drinking Water Quality: President Deputy Strategic Planning and Control," 1992 (in Persian). www.isiri.org

[8] World Health Organization, "Guidelines for DrinkingWater Quality: Recommen Dations," 2004.

[9] M. Gannadi, "Criteria and Guidelines for Analysis of Microbial Quality of Drinking Water," Water and Wastewater Company of Mashhad City, Mashhad, 2002 (in Persian).

[10] M. Ghaderpoori, M. H. Dehghani, M. Fazlzadeh and A. Zarei, "Study of Microbial Quality of Drinking Water in Rural Areas of Saqqez, Iran," American-Eurasian Journal of Agricultural \& Environmental Sciences, Vol. 5, No. 5, 2009, pp. 627-632.

[11] L. S. Clesceri, A. E. Greenberg and A. D. Eaton, "Standard Method for Examination of Water and Wastewater," American Public Health Association, Washington DC, 2005. 
[12] Institute of Standards and Industrial Research of Iran, "Microbial Properties of Drinking Water," 4th Edition, 1997 (in Persian). www.isiri.org

[13] World Health Organization, "Guidelines for DrinkingWater Quality," 2006.

[14] M. B. Miranzadeh, M. Heidari, A. R. Mesdaghinia and M. Younesian, "Survey of Microbial Quality of Drinking Water in Rural Areas of Kashan Iran in Second Half of 2008," Pakistan Journal of Biological Sciences, Vol. 14, No. 1, 2011, pp. 59-63. doi:10.3923/pjbs.2011.59.63

[15] P. W. Ramteke, J. W. Bhattacharj and S. P. Pathak, "Evaluation of Coliforms as Indicators of Water Quality in India," Journal of Applied Bacteriology, Vol. 72, No. 4, 1992, pp. 352-356. doi:10.1111/j.1365-2672.1992.tb01846.X

[16] A. H. Shar, Y. F. Kazi, M. Zardari and I. H. Soomro, "Bacteriological Quality of Drinking Water of Sukkur City," Pakistan Journal of Medical Research, Vol. 48, 2009, pp. 88-90.
[17] A. H. Shar, Y. F. Kazi, M. Zardari and I. H. Soomro, "Enumeration of Total and Fecal Coliform Bacteria in Drinking Water of Khairpur Sindh," Pakistan Journal of Medical Research, Vol. 47, 2008, pp. 18-21.

[18] Institute of Standards and Industrial Research of Iran, "Drinking Water-Physical and Chemical Specifications," 1998 (in Persian). www.isiri.org

[19] M. H. Dehghani, et al., "Microbial Quality of Drinking Water in Shadegan Township, Iran," World Applied Sciences Journal, Vol. 13, No. 1, 2011, pp. 114-118.

[20] A. Mokhtari , M. Fazlzadeh and B. Dorraji, "Study of Microbial Quality of Drinking Water in Rurals of Ardabil," Ardabil Health Journal, Vol. 2, No. 1, 2010, pp. 3240 (in Persian).

[21] World Health Organization, "Safe Piped Water-Managing Microbial Water Quality in Piped Distribution Systems," 2004.

[22] G. S. Bridie, "Water Supply and Sanitation Engineering," Sita Ram Bazar, New Dehli, 2000. 